\section{The state of the HEA}

This has been a hectic spring for Congress, although many issues remain up in the air as political anxieties stir the agenda.

The Higher Education Act reauthorization (HEA) continues to move through both houses of Congress. The House passed H.R. 6; the Senate version, S. 1882, has now been reported out of committee, but the bill has not gone to the Senate floor. Once the Senate passes S. 1882, the House-Senate conference committee will start work with the act, almost assuredly being passed before the end of this congressional session. The focus of HEA remains on student aid and related finance issues. Conferees will have to agree on whether to decrease the student local interest rates, whether to increase Pell grant limits by $\$ 100$, and similar student aid issues.

\section{International information access}

H.R. 6 did include a provision as part of Title VI on the international studies initiatives, which would replace the current program for periodical and other research materials published outside of the United States with a new technological innovation and cooperation for a foreign information access program. The purpose of the program is to develop innovative techniques or programs using new electronic technologies to collect, organize, preserve, and widely disseminate information on world regions and countries that address critical areas the nation's teaching and research needs in international education and foreign languages.

\section{Intellectual property legislation}

Intellectual property legislation remains active on at least two fronts: The World Intellectual Property Organization (WIPO) Treaty Implementation legislation was approved by the full Senate (S. 2037) in mid-May and cleared by the House Judiciary Committee in early April as H.R. 2281. This sets the stage for further consideration by the House Commerce Committee and perhaps the full House of Repre-

Lynne E. Bradley is deputy executive director of ALA's Washington Office; e-mail: leb@alawash.org sentatives in the coming weeks. While changes were made in the Senate's bill to permit the use of digital technology to make multiple preservation copies of a work, and a Copyright Office study was commissioned on updating the Copyright Act's outdated distance education provisions, the Senate's bill still fails to adequately protect and extend fair use into the digital network environment. ACRL library supporters are urged to contact their member of Congress immediately and ask that they: oppose H.R. 2281 and cosponsor H.R. 3048, library-friendly legislation by Reps. Rick Boucher (D-Virginia) and Tom Campbell (RCalifornia).

\section{Database protection legislation halted}

Database Protection legislation, with the serious potential to interfere with research of all kinds and impede public access to information not entitled to copyright protection, has been approved by the House Judiciary Committee as H.R. 2652 and awaits consideration by the full House of Representatives. No comparable legislation is pending in the Senate. With the active assistance of ACRL, ALA, and many others in the public and private sector launched a successful campaign to keep this bill from coming to the floor on May 12 under a procedure usually reserved for noncontroversial legislation. It is certain to be called up for a vote again shortly; all library supporters are urged to continue contacting their representatives in the House to request that they oppose H.R. 2652 in substantially the same form as reported by the Judiciary Committee.

\section{Increased funding for NAL}

The debate on appropriations continues. Here also, ACRL members have been most helpful in the efforts to assure increased funding for the National Agriculture Library (NAL). Its funding has been essentially frozen for several years. There is now an active campaign among library supporters and others to seek at least a modest $\$ 3$ million increase in funding for preservation, digital resource development, as well as collection development for NAL. 